\title{
Pola Pengalaman Depresi Perempuan yang Mengalami Kekerasan dalam Berpacaran: Kajian Perspektif Cognitive-Behavioural
}

\section{The Pattern of Depression in Women with Dating Violence Experiences: A Cognitive-Behavioural Perspective Study}

\author{
Stefanus Perangin-Angin ${ }^{1}$, Sutarto Wijono ${ }^{2}, \mathcal{E}$ Arianti Ina Restiani Hunga ${ }^{3}$ \\ 1,2Fakultas Psikologi, ${ }^{3}$ Fakultas Ilmu Sosial \\ Universitas Kristen Satya Wacana
}

\begin{abstract}
This review aimed to investigate the suitability of therapy derived from CognitiveBehavioural perspective to be applied as an intervention to treat depressive symptoms in women with dating violence experiences. As this will become a preliminary study to be conducted in Indonesia, a review literature method was employed to gather relevant and up-to-date materials on the topic. Firstly, the issue of dating violence and its urgency in Indonesia were described in the introduction section. In the discussion section, Cognitive-Behavioural perspective and the therapy derived from it, Cognitive Behavioural Therapy (CBT) was described and elaborated in detail. In general, CBT approach was effective in reducing depressive symptoms in women with intimate partner violence (IPV) experiences. As dating violence also belonged to IPV cluster, it is expected that CBT would also become an effective treatment to treat depression in women with dating violence experiences.
\end{abstract}

Keywords: approach perspective; cognitive-behavior; intimate partner violence; review literature

Abstrak. Tinjauan ini bertujuan untuk menyelidiki mengenai kesesuaian terapi yang berasal dari perspektif Cognitive-Behavioural untuk diterapkan sebagai intervensi untuk mengobati gejala depresi pada perempuan yang mengalami kekerasan dalam berpacaran. Karena penelitian ini akan menjadi studi pendahuluan yang akan dilakukan di Indonesia, metode tinjauan literatur digunakan untuk mengumpulkan materi yang relevan dan terkini tentang topik ini. Pertama, masalah kekerasan dalam berpacaran dan urgensinya di Indonesia dijelaskan di bagian pengantar. Pada bagian pembahasan, perspektif Cognitive-Behavioural dan terapi yang berasal dari perspektif ini, Cognitive Behavioural Therapy (CBT) dijelaskan dan diuraikan secara rinci. Secara umum, pendekatan CBT efektif dalam mengurangi gejala depresi pada perempuan dengan pengalaman Intimate Partner Violence (IPV). Karena kekerasan dalam berpacaran juga termasuk dalam kelompok rumpun IPV, diharapkan bahwa CBT juga akan menjadi terapi yang efektif untuk mengobati depresi pada perempuan yang mengalami kekerasan dalam berpacaran.

Keywords: approach perspective; cognitive-behavior; intimate partner violence; review literature

\section{Pengantar}

Pada skala global, menurut World Health Organization (2013a), frekuensi kekerasan terhadap perempuan meningkat dengan

\footnotetext{
${ }^{1}$ Korespondensi mengenai artikel ini dapat melalui: stefanus.kho@gmail.com;

wijonosutarto@gmail.com; inahunga@gmail.com
}

pesat. Di negara-negara Barat, seperti di Amerika Serikat, kekerasan terhadap pasangan perempuan atau Intimate Partner Violence (IPV) telah menjadi sebuah masalah kesehatan publik yang serius dan kompleks (Centers for Disease Control and Prevention, 2014). Survei berskala nasional di Amerika Serikat menunjukkan bahwa 
satu dari empat perempuan di negara tersebut akan mengalami kekerasan dari pasangannya minimal sekali selama masa hidupnya (Breiding, Black, \& Ryan, 2008). Konsekuensi terhadap kesehatan mental akibat kekerasan terhadap pasangan perempuan juga membebani biaya pengobatan dan kesehatan di Amerika Serikat (Rivara et al., 2007). Sedangkan di kawasan lain, menurut World Health Organization (2013a), kasus kekerasan terhadap perempuan memiliki prevalensi yang sangat tinggi di kawasan Asia Tenggara (37,7\%), wilayah Mediterania Timur (37\%) dan Afrika (36,6\%). Menurut Baldwin (2012), dalam penelitian yang dilakukan oleh Thomson Reuters Foundation terhadap 63 negara, menunjukkan bahwa setelah India dan Arab Saudi, Indonesia merupakan negara terburuk ketiga bagi perempuan dengan tingginya insiden kasus kekerasan terhadap perempuan (KTP) di Indonesia. Sedangkan laporan dari Thomson Reuters Foundation (2017), menunjukkan bahwa Jakarta merupakan kota terburuk nomor sembilan di dunia dalam hal KTP baik dalam kekerasan fisik maupun seksual.

Data yang dihimpun oleh Komisi Nasional (Komnas) anti kekerasan terhadap perempuan di Indonesia menunjukkan bahwa pada tahun 2011 ada 119.107 kasus kekerasan terhadap perempuan (KTP) Komnas Perempuan (2012). Pada tahun 2012, jumlah ini meningkat menjadi 216.156 kasus Komnas Perempuan (2013). Sedangkan pada tahun 2013, jumlah kasus kekerasan terhadap perempuan di Indonesia meningkat lagi menjadi 279.688 kasus Komnas Perempuan (2014). Pada 2014 hingga 2017, juga terjadi peningkatan kasus dari 293.220 kasus menjadi 348.446 kasus KTP (Komnas Perempuan, 2015, 2016, 2017, 2018).
Sementara itu, data yang masuk ke lembaga mitra pengada layanan Komnas Perempuan pada tahun 2013, menunjukkan ada 16.403 kasus KTP dan 71\% dari kasus tersebut terjadi di ranah personal Komnas Perempuan (2014). Pada tahun tersebut, jumlah kasus kekerasan dalam berpacaran (KDP) yang dilaporkan ke lembaga mitra pengada pelayanan mencapai 2507 kasus Komnas Perempuan (2014). Komnas Perempuan (2016) juga mencatat pada tahun 2015 terdapat 16.217 kasus KTP yang didata lembaga mitra pengada layanan dan 2734 kasus dari total kasus di atas, dikategorikan ke dalam ranah kasus KDP. Sementara pada tahun 2017, tercatat ada 13.384 kasus KTP yang didata oleh lembaga mitra pengada layanan Komnas Perempuan dan sebanyak 1873 kasus dari total kasus diatas, dikategorikan sebagai kasus KDP (Komnas Perempuan, 2018).

Konsekuensi yang ditimbulkan kasus KDP juga serius. Yang pertama adalah kehamilan yang tidak diinginkan (KTD). Secara global, menurut World Health Organization (2013b), 38\% dari kehamilan yang terjadi di dunia setiap tahunnya merupakan KTD. Angka ini mencapai 80 juta kehamilan per tahunnya. Lebih lanjut, menurut World Health Organization (2013b), dari jumlah KTD tersebut, per tahunnya ada 34 juta jiwa kelahiran yang tidak dikehendaki, 4 juta jiwa berakhir dengan keguguran, dan 42 juta janin diaborsi. Sementara di Indonesia, menurut Sinaga (2007), diperkirakan ada 1 juta remaja yang hamil di luar menikah setiap tahunnya. Menurut United Nations (2011), diperkirakan ada 1,7 juta perempuan di bawah usia 24 tahun hamil dan melahirkan setiap tahunnya di Indonesia, dan sekitar 500 ribu diantaranya masih berusia remaja. 
Masalah kedua adalah timbulnya pernikahan usia dini. Pada 2012, di Indonesia, kelompok usia yang memiliki persentase pernikahan tertinggi adalah kelompok perempuan berusia 15-19 tahun Badan Pusat Statistik (2012). Data ini diperkuat dengan penelitian dari UNICEF (2016) yang menunjukkan bahwa 1 dari 4 perempuan di Indonesia, menikah di bawah usia 18 tahun. Lebih lanjut, menurut Badan Pusat Statistik (2012), salah satu penyebab terjadinya pernikahan di usia dini adalah terjadinya kehamilan yang tidak diinginkan. Masalah pernikahan di usia dini ini juga memiliki dampak negatif, karena menurut Santrock (2012), kondisi emosional remaja masih labil dan meledak-ledak. Hal ini dapat berdampak buruk bagi perkembangan psikologis dan emosional baik untuk orang tua maupun anak yang mereka asuh Santrock (2012).

Secara psikologis, perempuan korban kekerasan dalam berpacaran (KDP) juga dapat mengalami gejala stres, depresi, gangguan kecemasan, kesulitan berkonsentrasi, insomnia, dan memiliki penghargaan diri yang rendah terhadap dirinya sendiri Safitri (2013). Marcelina (2008) menambahkan bahwa perasaan malu terhadap diri sendiri juga sering dialami perempuan korban KDP. Sedangkan penelitian dari Ayu, Hakimi, dan Hayati (2016) juga menunjukkan bahwa perempuan korban KDP dapat mengalami perasaan rendah diri dan perasaan dendam, benci, dan ketidakpercayaan terhadap laki-laki. Konsekuensi lain yang umum terjadi pada perempuan korban IPV dan KDP adalah Post-Traumatic Stress Disorder (PTSD) (Iverson et al., 2011). Terjadinya depresi pada perempuan korban IPV dan KDP juga merupakan hal yang umum terjadi (Iverson et al., 2011).
Menurut Iverson et al. (2011), gejala-gejala depresi dapat meningkatkan risiko terjadinya IPV dan KDP terhadap perempuan, karena depresi dapat mereduksi kemampuan kognitif dan afektif seseorang untuk mendeteksi pemicu terjadinya kekerasan, mendeteksi orangorang yang berpotensi melakukan kekerasan, dan mengambil tindakan untuk menghindari risiko kekerasan. Gejala depresi seperti perasaan bersalah, tidak berharga, tidak berdaya, dan tidak berpengharapan juga dapat menghambat seorang perempuan untuk keluar dari sebuah abusive relationship. Menurut Cougle, Resnick, \& Kilpatrick (2009), motivasi dan tingkat energi yang rendah yang juga merupakan karakteristik daripada depresi dapat menghambat seseorang untuk dapat segera keluar dari situasi yang membahayakan atau berpotensi menimbulkan kekerasan.

Salah satu intervensi yang akan dibahas dalam review ini untuk membantu mereduksi gejala-gejala depresi pada korban KDP, sehingga dapat membantu untuk menurunkan risiko terjadinya kekerasan berulang di masa mendatang adalah Cognitive Behavioural Therapy (CBT). Penelitian dari Iverson, Lester, dan Resick (2011) menunjukkan bahwa CBT dapat mereduksi gejala depresi pada korban IPV pada umumnya. Meta-analisis dari Cuijpers et al. (2014) juga menunjukkan bahwa psikoterapi dapat memberikan kontribusi yang positif terhadap meningkatnya kondisi psikologis pasien dengan kondisi depresi. Berdasarkan review sistematis dari Trabold, McMahon, Alsobrooks, Whitney, dan Mittal (2018), CBT dapat secara signifikan menurunkan tingkat depresi pada perempuan yang mengalami intimate partner violence. Karena kasus KDP merupakan contoh kasus yang spesifik dari kasus IPV, maka perspektif 
Cognitive-Behavioural juga seharusnya dapat diaplikasikan pada populasi perempuan yang mengalami KDP secara khususnya. Tujuan dari review literatur ini adalah untuk mendeskripsikan mengenai perspektif Cognitive-Behavioural dan CBT, serta menjelaskan bagaimana terapi ini dapat menjadi sebuah terapi yang tepat untuk memulihkan kondisi depresi pada perempuan yang mengalami KDP.

\section{Pembahasan}

\section{Model Cognitive-Behavioural}

Model Cognitive-Behavioural pertama kali dikembangkan oleh Aaron T. Beck, MD (Scott \& Freeman, 2010). Menurut Comer (2010), model ini dapat menjelaskan bagaimana depresi dapat terjadi dalam hidup seorang individu. Beck, Rush, Shaw, dan Emery (1979) menjelaskan bahwa, dalam model ini, faktor utama yang menyebabkan terjadinya gangguan kejiwaan, seperti depresi, pada seseorang adalah terdapatnya pola pikir yang keliru atau terdistorsi pada individu tersebut mengenai dirinya sendiri dan situasi yang dialaminya. Menurut Beck et al. (1979), pola pikir yang terdistorsi dan maladaptif ini dapat menyebabkan timbulnya perilaku yang maladaptif pula. Beck (2005) juga melakukan review retrospektif terhadap model ini. Secara umum, menurut Beck, model ini telah banyak diteliti dan digunakan sebagai framework intervensi dan terapi untuk berbagai jenis gangguan psikologis. Secara khusus, model ini juga digunakan sebagai kerangka konseptual untuk menjelaskan terjadinya kondisi depresi pada individu Beck (2005). Beck menyatakan bahwa kerangka konseptual ini dapat menjadi acuan dalam memformulasikan strategi penanganan yang tepat pada individu yang mengalami depresi.
Dalam review tersebut, Beck (2005) juga menjelaskan bahwa salah satu elemen penting dari model ini adalah negative cognitive triad. Dalam negative cognitive triad, dijelaskan bahwa ada tiga komponen yang menjadi elemen kunci penyebab timbulnya depresi pada seorang individu yaitu individu tersebut memandang dirinya sendiri, dunia ini, dan masa depan dari sudut pandang yang negatif Beck (2005). Dalam kaitannya dengan negative cognitive triad ini, Beck menjelaskan dalam penelitiannya bahwa dari 164 penelitian yang direview, 150 penelitian mendukung pernyataannya bahwa pola negative cognitive triad selalu terdapat dalam pemikiran individu yang sedang mengalami depresi.

Scher, Ingram, dan Segal (2005) mendeskripsikan elemen penting lain dalam model ini. Mereka menyatakan bahwa elemen krusial yang menyebabkan timbulnya depresi pada seseorang ialah terdapatnya pola pemikiran negatif yang tidak membangun dan disebut sebagai unhelpful thoughts. Pola pemikiran ini terjadi pada saat individu tersebut sedang mengalami suatu periode pengalaman yang menimbulkan stres dalam hidupnya, seperti misalnya mengalami kasus perceraian, kematian seorang anggota keluarga yang dikasihi, ataupun mengalami kekerasan dalam rumah tangga atau dalam ranah berpacaran. Menurut Scher et al. (2005) terjadinya kondisi depresi dalam hidup seseorang dapat dipicu oleh kejadian atau insiden kritis semacam ini.

Kekerasan dalam Berpacaran dalam Framework Teori Ekologi Bronfenbrenner

Salah satu framework teori komprehensif yang dapat diaplikasikan dalam fenomena kekerasan secara umum adalah framework teori ekologi. Bronfenbrenner (1977) menciptakan model teori ekologi yang 
pertama dan model ini menjelaskan bagaimana perilaku dan perkembangan seorang individu dipengaruhi oleh interaksi-interaksi dari beberapa sistem. Teori ekologi ini terdiri dari empat sistem yang saling berelasi satu sama lain yaitu: 1) Mikrosistem (lapisan terdalam dalam teori ekologi yang terdiri dari lingkungan di mana individu berinteraksi secara langsung dengannya, contohnya seperti lingkungan rumah, sekolah, dan tempat bekerja), 2) Mesosistem (inter-relasi dan interaksi dari dua atau lebih mikrosistem, seperti interaksi antara lingkungan rumah dan sekolah), 3) Eksosistem (konteks lingkungan di mana individu tidak memiliki kontak secara langsung dengan konteks ini, tetapi tetap memiliki dampak terhadap individu tersebut, seperti komunitas yang lebih luas di mana individu tinggal), dan 4) Makrosistem (lapisan terluar dalam teori ekologi yang terdiri dari nilai-nilai budaya pada konteks masyarakat yang lebih umum) Bronfenbrenner (1977). Bronfenbrenner (2004) kemudian menambahkan sistem kelima dalam teori ini yaitu kronosistem, yang mendeskripsikan kejadian-kejadian historis dan masa-masa transisi yang dapat memberi dampak pada sistemsistem yang lainnya.

Teori ekologi telah banyak diaplikasikan dalam literatur dan penelitian mengenai kekerasan. Banyard (2011) menyatakan bahwa framework teori ekologi ini cocok digunakan untuk mengamati fenomena masalah kekerasan, karena framework ini mengamati sebuah masalah dari berbagai aspek yang berbeda seperti aspek individual, lingkungan, situasional, dan faktor-faktor sosiokultural terkait lainnya. Teori ekologi telah digunakan sebagai guiding framework dalam topik penelitian kekerasan seperti penelitian mengenai Intimate Partner Violence
(Alaggia, Regehr, \& Jenney, 2012; Weeks \& LeBlanc, 2011) dan juga penelitian mengenai kekerasan dalam berpacaran (Connolly, Friedlander, Pepler, Craig, \& Laporte, 2010). Menurut Banyard (2011), teori ekologi dapat menjadi sebuah framework yang dapat digunakan untuk memahami fenomena kekerasan dalam berpacaran dengan cara mengeksplorasi konteks di mana individu berada, mulai dari mikrosistem sampai menuju kepada makrosistem.

Dalam mikrosistem, ada beberapa faktor dalam sistem ini yang dapat memberi dampak terhadap kekerasan dalam berpacaran (KDP). Menurut Foshee et al. (2011), lingkungan keluarga dan keberfungsian relasi dalam keluarga adalah dua faktor yang penting dalam mikrosistem. Sehingga, faktor-faktor seperti tingginya tingkat konflik dalam keluarga, perceraian orang tua, hubungan orang tua-anak yang tidak harmonis, dan kurangnya support dan monitoring dari orang tua terhadap anak berhubungan dengan meningkatnya risiko timbulnya KDP pada anak setelah anak beranjak remaja atau dewasa muda (Foshee et al., 2011; Vagi et al., 2013). Menurut Vagi et al. (2013), terpaparnya anak pada kekerasan di lingkungan keluarga dalam bentuk mengalami kekerasan secara langsung dari orang tua dan/atau menyaksikan secara langsung terjadinya kekerasan terhadap istri oleh suami, dapat meningkatkan risiko anak untuk melakukan KDP atau menjadi korban KDP ke depannya.

Lingkungan peer group juga dapat memengaruhi terjadinya KDP, terutama dalam mikrosistem. Menurut Foshee, Reyes, dan Ennett (2010), keterlibatan dalam peer group yang berperilaku antisosial, memiliki peer group yang juga melakukan KDP, atau berada dalam peer group yang melakukan tindakan kekerasan 
dalam bentuk apapun, berkorelasi dengan meningkatnya risiko individu tersebut menjadi pelaku KDP.

Interaksi antara beberapa mikrosistem di atas dapat disebut sebagai mesosistem. Menurut Vagi et al. (2013), interaksi antara mikrosistem dalam konteks KDP ini (seperti interaksi lingkungan keluarga yang buruk dengan lingkungan peer group yang buruk) dapat memengaruhi perilaku individu dan menyebabkan individu tersebut terbiasa untuk berkonflik dalam hal berelasi dengan orang lain, memiliki sifat agresif, memiliki communication skill yang buruk, dan kurang memiliki skill yang baik dalam hal resolusi konflik. Faktor-faktor ini dapat menjadi faktor risiko yang menyebabkan timbulnya konflik dalam relasi, termasuk juga dalam relasi berpacaran (Vagi et al., 2013). Konflik dalam relasi berpacaran dapat menjadi pemicu terjadinya kekerasan dalam relasi berpacaran tersebut (Vagi et al., 2013).

Pada sistem selanjutnya yaitu eksosistem, ada beberapa faktor dalam level komunitas yang berhubungan dengan KDP. Penelitian terdahulu menemukan bahwa paparan terhadap kekerasan di dalam komunitas, misalnya di lingkungan tempat tinggal atau tempat kerja, berasosiasi dengan meningkatnya insiden KDP di komunitas tersebut (Foshee et al., 2011; Vagi et al., 2013). Faktor-faktor lain pada eksosistem yang juga berhubungan dengan KDP adalah support dan monitoring komunitas terhadap populasi remaja dan dewasa muda di komunitas tersebut (Foshee et al., 2011; Jain, Buka, Subramanian, \& Molnar, 2010). Insiden KDP di komunitas dapat meningkat apabila support dan monitoring komunitas terhadap populasi remaja dan dewasa muda rendah (Foshee et al., 2011; Jain et al., 2010).
Sistem selanjutnya adalah makrosistem. Menurut Connolly et al. (2010), paparan terhadap gambar dan berita mengenai kekerasan di media massa dapat memengaruhi persepsi individu terhadap KDP. Connolly et al. menyatakan bahwa norma sosial-budaya mengenai peran gender dan hubungannya terhadap kekerasan secara umum juga dapat memengaruhi persepsi seseorang mengenai KDP. Norma sosial-budaya seperti sikap yang toleran terhadap kekerasan yang dilakukan oleh laki-laki, dapat meningkatkan risiko terjadinya insiden KDP (Connolly et al., 2010). Connolly et al. (2010) juga berpendapat bahwa perilaku kekerasan dan agresivitas terhadap orang lain yang ditampilkan di media massa dapat menjadi model negatif bagi individu remaja dan dewasa muda dalam hal berperilaku. Menurut mereka, hal ini berpotensi untuk meningkatkan penerimaan terhadap norma-norma perilaku kekerasan dan dapat meningkatkan risiko terjadinya kekerasan dalam relasi berpacaran.

Pola Pengalaman Depresi Perempuan yang Mengalami Kekerasan dalam Berpacaran

Dalam Diagnostic and Statistical Manual Fifth Edition (American Psychiatric Association, 2013), dijelaskan bahwa ada beberapa gejala utama dari depresi. Yang pertama adalah gangguan suasana hati yang persisten dan depresif selama minimal dua minggu, kehilangan minat dalam melakukan aktivitas yang sebelumnya disukai, dan mengalami kelelahan fisik yang berlebihan. Gejala yang lainnya adalah konsentrasi yang menurun, mudah merasa marah atau teriritasi, insomnia atau mengalami gangguan tidur, perubahan pada berat badan (berat badan dapat meningkat secara signifikan atau menurun secara signifikan), mengalami 
rasa bersalah atau tidak percaya diri, dan adanya pemikiran untuk bunuh diri.

Menurut Beck et al., (1979), model Cognitive-Behavioural dapat menjelaskan mengenai pengalaman depresi yang dialami oleh seorang individu. Beck et al. menyatakan bahwa dalam model ini, pola pemikiran dan interpretasi seseorang terhadap situasi yang dialaminya menentukan apakah situasi tersebut dapat menjadi pemicu timbulnya sebuah gangguan psikologis seperti depresi. Dengan kata lain, menurut Beck et al., proses pemikiran seseorang akan mewarnai sudut pandang, perasaan, dan perilaku orang tersebut. Salah satu cara untuk memahami gangguan psikologis seorang individu adalah dengan cara meneliti mengenai proses berpikir individu tersebut. Menurut model ini, pola pemikiran seseorang dapat dibentuk dari pengalaman masa lalu atau pengalaman masa kecilnya, baik itu dari pengalamanpengalaman yang positif maupun pengalaman-pengalaman yang negatif (Beck et al., 1979).

Menurut Ellis dan Dryden (2007), pola pikir yang berkontribusi terhadap depresi ini dapat berkembang menjadi sebuah depresi mayor apabila ada sebuah insiden yang memicu dan mengaktivasi pemikiran tersebut. Insiden ini dapat berupa kekerasan dalam rumah tangga atau juga kekerasan dalam ranah berpacaran yang dialami oleh seorang perempuan. Seorang individu yang mengalami depresi biasanya melihat dirinya sendiri, dunia ini, dan masa depan dalam sudut pandang yang negatif. Menurut Beck et al. (1979), individu yang mengalami depresi juga memandang masalahnya dengan cara yang negatif. Individu ini dapat melihat masalahnya sebagai suatu masalah yang tanpa akhir dan tidak ada solusinya, serta membayangkan bahwa masa depannya akan diwarnai dengan masalah yang sama. Menurut Beck et al. jenis pola pikir seperti ini dapat menyebabkan seseorang mengalami depresi mayor. Beck et al. juga menjelaskan bahwa terdapat jenis pemikiran negatif lain yang dapat menyebabkan seseorang mengalami depresi. Yang pertama adalah jenis pemikiran melompat pada kesimpulan. Dalam konteks KDP, contoh pola pikir ini adalah: "Jika pasanganku meninggalkanku maka hidupku akan menjadi sulit dan hampa, oleh karena itu aku memilih untuk tetap bertahan walau disakiti". Menurut Beck et al., dalam jenis pemikiran ini, seorang perempuan akan membuat sebuah kesimpulan tertentu mengenai permasalahannya tanpa didukung oleh data dan fakta yang jelas.

Kedua adalah jenis pemikiran mengecilkan atau memperbesarkan masalah. Menurut Beck et al. (1979), seorang individu dapat mengecilkan hal-hal baik yang dialami dalam hidupnya atau membesar-besarkan hal-hal negatif yang terjadi dalam kehidupannya. Dalam konteks KDP, contoh pola pikir mengecilkan masalah adalah: "Dia (pasanganku) memukul dan mengata-ngatai saya pasti karena dia mencintai saya". Yang ketiga adalah pola pemikiran hitam atau putih. Dalam pola pemikiran ini, seorang perempuan yang mengalami KDP melihat dirinya sepenuhnya negatif dan gagal melihat hal-hal positif lain dalam kehidupannya. Walaupun ada hal positif, kelebihan, dan kekuatan yang dimilikinya, dia gagal untuk melihat hal-hal tersebut secara benar dan seimbang. Contohnya adalah: "Saya pastinya adalah orang yang kotor dan tak berharga, karena saya tak bisa untuk menyenangkan hati pasangan saya".

Sebagai kesimpulan, menurut Beck et al. (1979), pola pemikiran terdistorsi ini 
membantu mempertahankan kepercayaan negatif dalam diri perempuan dan pada akhirnya juga membantu mempertahankan siklus negatif depresi.

\section{Cognitive Behavioural Therapy}

Cognitive Behavioural Therapy (CBT) adalah sebuah jenis terapi yang dapat digunakan untuk menangani kasus depresi Comer (2010). Gloaguen, Cottraux, Cucherat, dan Blackburn (1998) membuat meta-analisis mengenai 48 studi Randomized-Controlled Trial menggunakan CBT sebagai terapi untuk pasien depresi. Mereka menyimpulkan bahwa untuk pengobatan depresi ringan dan sedang, CBT secara signifikan lebih efektif dibandingkan dengan pengobatan anti-depresan atau grup kontrol yang tidak menerima terapi. Menurut Strunk dan DeRubeis (2001), CBT setidaknya mempunyai efek yang sama baiknya dengan pengobatan anti-depresan dalam penanganan kasus depresi berat. Namun Hollon (2003) menambahkan bahwa dalam jangka panjang CBT mempunyai efek yang lebih long-lasting jika dibandingkan dengan farmakoterapi.

Pada fase-fase awal CBT, biasanya terapis akan memberikan terapi aktivitas kepada klien untuk membantu klien menjadi lebih aktif sehingga dapat meningkatkan mood klien Comer (2010). Menurut Comer, dalam terapi aktivitas, terapis membantu klien untuk menjadwalkan dan melakukan aktivitas yang produktif dan menyenangkan untuk dilakukan oleh klien. Dalam fase selanjutnya, menurut Beck et al. (1979) terapis akan membantu klien untuk memahami, mengenal, dan mengubah cara berpikirnya yang maladaptif. Terapis akan membantu klien untuk memahami bahwa kepercayaan dan pola pikirnya yang negatif terhadap situasinya adalah masalah yang sebenarnya dan yang membuat klien menjadi depresi. Selanjutnya, menurut Beck et al., terapis akan membantu klien untuk mengenali pola-pola pemikirannya yang keliru dan membantu klien untuk mengganti pola pikir tersebut dengan pemikiran yang lebih seimbang dan positif. Perubahan secara gradual dalam diri klien akan terjadi setelah adanya perubahan dalam cara klien berpikir (Beck et al., 1979).

Dalam CBT juga terdapat komponen perilaku. Komponen ini juga dimasukkan sebagai bagian dari rencana program terapi. Menurut Dobson (2010), contoh dari komponen ini adalah eksperimen perilaku. Contoh eksperimen perilaku adalah pada saat klien yang depresi berkata, "Saya gagal dalam segala hal, sehingga tidak ada gunanya berusaha". Salah satu cara untuk mengatasi masalah ini adalah dengan menggunakan eksperimen perilaku sebagai tugas yang diujicobakan diluar sesi terapi. Dalam eksperimen ini, klien berusaha untuk melakukan aktivitas atau tugas yang sebenarnya dia hindari. Diharapkan dengan melakukan eksperimen perilaku ini, klien dapat keluar dari siklus avoidance dan pada akhirnya dapat juga digunakan untuk menantang dan mengubah kognisi awalnya yang menyatakan bahwa kegagalan adalah hal yang pasti terjadi dan oleh sebab itu tidak ada manfaatnya untuk melakukan tugas tersebut (Dobson, 2010).

Teknik-Teknik Umum dalam Cognitive Behavioural Therapy

Ada berbagai macam prinsip dan teknik klinis yang termasuk dalam praktek CBT. Dua prinsip utama dalam CBT adalah kolaborasi dan guided empiricism (Young, Rygh, Weinberger, \& Beck, 2008). Kolaborasi dalam konteks CBT adalah sebuah proses bekerjasamanya terapis dengan 
klien untuk membahas masalah yang paling utama bagi klien dan juga untuk mendiskusikan target pencapaian terapi pada setiap sesinya. Guided empiricism adalah sebuah proses kerja sama antara terapis dengan klien melalui pendekatan saintifik dalam hal kognisi dan perilaku, di mana terapis melakukan proses investigasi problem, membentuk hipotesis mengenai problem yang dihadapi klien, dan mendorong klien untuk berpikir dan berperilaku dengan cara yang berbeda untuk menguji kebenaran hipotesis tersebut. Proses kolaborasi dan guided empiricism digunakan untuk membantu klien untuk mengembangkan sebuah formulasi dan pemahaman mengenai bagaimana problem dari klien bertahan dan terus berputar dalam sebuah siklus yang negatif. Pengembangan formulasi masalah klien adalah bagian yang utama dari sebuah intervensi CBT, karena formulasi membantu dalam memandu pengidentifikasian kognisi dan perilaku yang perlu ditangani dalam sesi terapi (Beck et al., 1979).

Teknik kognitif yang digunakan dalam intervensi CBT adalah psikoedukasi dan penstrukturan-ulang kognitif. Psikoedukasi adalah sebuah proses di mana terapis memberikan pemahaman kepada klien mengenai penyebab dari masalahnya dan bagaimana masalah tersebut bertahan dalam sebuah siklus negative (Craske \& Barlow, 2008). Psikoedukasi digunakan terapis untuk menolong klien untuk membedakan antara pikiran dan perasaan, membedakan jenis-jenis pikiran (pikiran otomatis dan core beliefs), dan bagaimana caranya untuk melakukan aktivitas selfmonitoring (Cormier \& Nurius, 2003). Setelah psikoedukasi, biasanya terapis akan melakukan penstrukturan-ulang kognitif, yang meliputi pengidentifikasian pola pikir yang maladaptif dan menggunakan disputasi kognitif untuk mengubah pola pikir tersebut (Cormier \& Nurius, 2003). Proses disputasi kognitif ini dapat menolong klien untuk mengembangkan pola pikir yang adaptif dan berdasarkan pada realitas dan kenyataan yang sebenarnya.

Ada beberapa jenis teknik perilaku yang digunakan dalam sesi terapi CBT, seperti exposure, teknik pemecahan masalah, dan aktivasi perilaku (Cormier \& Nurius, 2003). Beberapa tipe exposure yang dilakukan dalam CBT adalah desensitisasi sistematis, graded exposure, interoceptive exposure dan imaginal exposure Barlow (2008). Namun pada umumnya, setiap metode ini mempunyai prinsip pokok yang sama yaitu untuk menolong klien memutuskan siklus avoidance terhadap stimuli tertentu. Dengan keterlibatan klien dalam exposure, rantai antara pemicu (sebagai contoh: interaksi sosial dengan orang lain) dengan perilaku avoidance akan menurun sebagai akibat dari penerapan exposure tersebut. Sedangkan teknik pemecahan masalah adalah sebuah proses yang digunakan untuk menolong klien mengembangkan solusi alternatif terhadap masalah-masalah dalam kehidupannya dan membantu klien dalam melakukan pengambilan keputusan untuk memecahkan masalah yang dihadapi (Cormier \& Nurius, 2003). Aktivasi perilaku dapat digunakan untuk pengobatan depresi dan melibatkan pembuatan jadwal kegiatan aktivitas harian oleh klien dan dapat digunakan untuk memutuskan siklus avoidance yang dimiliki klien (Page \& Stritzke, 2006).

Penelitian Terdahulu mengenai Cognitive Behavioural Therapy dalam Konteks Kekerasan terhadap Pasangan Perempuan

Penelitian-penelitian sebelumnya mengenai CBT dalam konteks kekerasan terhadap pasangan perempuan telah 
banyak dilakukan. Menurut Trabold et al. (2018), intervensi CBT mempunyai potensi yang besar dalam menurunkan tingkat kekerasan dalam IPV jika dibandingkan dengan intervensi klinis lainnya. Dengan menggunakan sampel perempuan yang mengalami IPV dan menggunakan NAPZA, sebuah intervensi CBT yang dilakukan terbukti dapat menurunkan tingkat kekerasan yang dialami partisipan secara fisik dan seksual sebesar $50 \%$ dan hasil ini lebih baik jika dibandingkan dengan kelompok kontrol yang hanya mengalami penurunan sebesar 13\% (Gilbert et al., 2006). Gilbert et al. juga melaporkan bahwa penurunan dalam kekerasan verbal atau psikologis yang dialami partisipan terjadi sebesar 32\% dan hasil ini lebih tinggi jika dibandingkan dengan kelompok kontrol yang hanya mengalami penurunan sebesar $20 \%$. Penelitian Iverson et al. (2011) melaporkan bahwa terdapat penurunan kekerasan yang dialami oleh partisipan sebesar $40 \%$ setelah mengikuti sesi CBT sebanyak minimal 5-8 sesi.

Dalam konteks depresi, intervensi CBT juga menunjukkan hasil yang signifikan dalam menurunkan gejala depresi pada korban IPV. Intervensi CBT dilakukan dalam 8-12 sesi dan pada setiap sesi berdurasi selama 1-1.5 jam (Iverson et al., 2011; Johnson, Zlotnick, \& Perez, 2011). Dalam dua studi tersebut, gejala depresi korban IPV menurun secara signifikan pada follow-up satu minggu, tiga bulan, dan enam bulan setelah terapi jika dibandingkan dengan pada saat pre-test. CBT juga dapat diterapkan secara berkelompok dan terapi berkelompok ini juga menunjukkan hasil penurunan depresi yang signifikan pada korban yang mengalami kekerasan fisik maupun psikologis (Crespo \& Arinero, 2010). Menurut Iverson et al. (2011), semakin berat tingkat IPV yang dialami oleh seorang perempuan maka akan semakin berat depresi yang dialaminya. Sedangkan perempuan yang mengalami tingkat IPV yang lebih ringan dapat mengalami remisi depresi lebih cepat jika dibandingkan dengan perempuan yang mengalami tingkat IPV yang lebih berat (Iverson et al., 2011).

Intervensi klinis yang lain dilakukan oleh Reed dan Enright (2006). Intervensi ini juga didasarkan pada model CognitiveBehavioural. Dalam penelitian ini, mereka menggunakan forgiveness therapy dan mereka menemukan bahwa terdapat penurunan gejala depresi yang signifikan pada partisipan pada saat post-therapy. Dalam forgiveness therapy, partisipan berusaha memaknai kembali pengalaman IPV yang dialaminya dengan cara mengubah persepsinya mengenai pengalaman tersebut dan mengampuni pasangan mereka yang telah melakukan kekerasan terhadap mereka. Intervensi forgiveness therapy ini diberikan kepada perempuan yang sudah tidak menjalin hubungan dengan pasangannya selama minimal dua tahun.

Dalam konteks Psychological WellBeing (PWB), studi dari Johnson et al. (2011), menunjukkan bahwa terjadi peningkatan secara signifikan dalam PWB pada partisipan perempuan yang mengalami IPV setelah pemberian CBT. Secara umum, peningkatan terjadi pada aspekaspek PWB seperti self-esteem, self-efficacy, empowerment, dan social adjustment. Secara umum, dapat disimpulkan bahwa intervensi berdasarkan model CognitiveBehavioural dapat menurunkan depresi pada perempuan korban IPV karena (1) intervensi yang didasarkan pada model ini mempunyai elemen pemecahan masalah, dan (2) intervensi ini juga memfasilitasi perubahan pemikiran-pemikiran yang 
terdistorsi pada perempuan yang mengalami IPV. Pemikiran yang terdistorsi ini, berdasarkan model Cognitive-Behavioural, adalah sumber masalah utama dalam permasalahan depresi seorang individu.

\section{Implementasi Cognitive Behavioural Therapy} dalam Konteks Kekerasan terhadap Pasangan Perempuan

Hasil studi Trabold et al. (2018), menunjukkan bahwa intervensi yang berfokus pada pemberdayaan perempuan dan juga perspektif Cognitive-Behavioural dapat memberikan dampak yang positif pada penurunan depresi perempuan yang mengalami kekerasan dari pasangannya. Menurut Trabold et al., intervensi yang berfokus pada pemecahan masalah, pengambilan keputusan yang tepat, dan perubahan pada pola pikir dan persepsi yang terdistorsi dapat memfasilitasi terjadinya perubahan pada kesehatan fisik dan mental perempuan yang mengalami IPV dan KDP.

IPV adalah sebuah masalah kesehatan publik yang berskala global dan telah banyak diteliti dalam 30 tahun terakhir World Health Organization (2005). Menurut World Health Organization, IPV adalah suatu perilaku dalam relasi intim yang menyebabkan terjadinya kekerasan fisik, psikologis, dan seksual, seperti tindakan agresif (memukul dan menendang), verbal abuse, pemaksaan secara seksual, dan usaha mengontrol perilaku pasangannya. Menurut estimasi World Health Organization, sekitar 30\% perempuan di dunia ini mengalami kekerasan baik secara fisik maupun seksual oleh pasangannya. Penelitian Breiding, Chen, dan Black (2014) menunjukkan bahwa di Amerika Serikat, dari total keseluruhan jumlah perempuan yang mengalami IPV, $30 \%$ melaporkan terjadinya kekerasan fisik, 10\% mengalami kekerasan seksual atau diperkosa, dan $48 \%$ mengalami kekerasan secara psikologis. IPV juga berdampak secara finansial dalam skala global. Sebagai contoh, di Amerika Serikat diperkirakan biaya yang dikeluarkan negara sebagai biaya langsung pengobatan secara fisik dan mental, dan biaya tidak langsung berupa hilangnya produktivitas dan pendapatan adalah sebesar US\$ 8.3 miliar (Max, Rice, Finkelstein, Bardwell, \& Leadbetter, 2004). Perempuan yang mengalami kekerasan secara fisik oleh pasangannya juga lebih sering menggunakan pelayanan kesehatan dan menghabiskan biaya kesehatan yang lebih banyak jika dibandingkan dengan perempuan yang tidak mengalami kekerasan fisik oleh pasangannya (Bonomi, Anderson, Rivara, \& Thompson, 2009).

Walaupun IPV mengakibatkan meningkatnya biaya kesehatan langsung dan tak langsung, masih sedikit penelitian yang dilakukan untuk memvalidasi intervensi IPV yang tepat dan efektif digunakan untuk menangani korban maupun pelaku kekerasan IPV. Untuk menangani permasalahan IPV, penanganan perlu dilakukan dalam setiap lapis pelayanan kesehatan; baik dalam bidang primer (pencegahan kekerasan), sekunder (skrining untuk kasus IPV), dan tersier (pemberian konseling atau pelayanan klinis).

Teori pemberdayaan adalah sebuah teori yang berfokus pada peningkatan otonomi, kontrol, dan kemampuan individu untuk menciptakan kesempatan dan pengambilan keputusan yang baik bagi dirinya Zimmerman (1995). Penanganan kasus IPV yang berdasarkan pada teori ini biasanya meliputi: asesmen kebutuhan korban, menghubungkan korban ke komunitas pendukung atau organisasi yang tepat, safety planning, dan memberikan dukungan baik secara sosial 
maupun emosional kepada korban (Trabold et al., 2018). Intervensi lain yang bisa dilakukan adalah psikoedukasi (Kaslow et al., 2010). Intervensi ini dapat menjadi komponen yang penting pada intervensi yang didasarkan pada teori pemberdayaan maupun intervensi klinis seperti CBT. Dalam kaitannya dengan kekerasan terhadap pasangan perempuan, psikoedukasi dapat berupa memberikan penjelasan kepada perempuan mengenai kondisi IPV, KDP, gejala-gejala depresi, dan PTSD. Menurut Kaslow et al. (2010), psikoedukasi juga dapat berupa pemberian penjelasan kepada korban mengenai safety planning dan positive parenting dalam kaitannya dengan IPV.

Secara umum, terapi yang berfokus pada teori pemberdayaan hanya menunjukkan hasil yang signifikan pada jangka pendek dalam hal penurunan gejala depresi (Constantino et al., 2015). Menurut Constantino et al., dalam jangka menengah dan jangka panjang, efek dari terapi ini menurun sehingga tidak ditemukan adanya perbedaan yang signifikan baik secara klinis maupun statistik antara grup yang menerima intervensi dan grup kontrol. Dalam studi lain oleh Sullivan, Bybee, dan Allen (2002), menggunakan intervensi yang berfokus pada teori pemberdayaan, mereka menemukan adanya penurunan gejala depresi sebesar $42 \%$ dari partisipan yang mengalami IPV pada post-intevensi. Walau demikian, penurunan gejala ini hanya berhasil dipertahankan selama empat bulan post-intervensi dan pada 24 bulan post-intervensi, tidak ditemukan perbedaan yang signifikan dalam penurunan depresi pada grup intervensi jika dibandingkan dengan grup kontrol.

Dalam hubungannya dengan PWB, secara umum, terdapat peningkatan PWB pada partisipan dan peningkatan ini dapat dipertahankan sampai dua tahun postintervensi (Trabold et al., 2018). Peningkatan ini juga terlihat pada kedua tipe intervensi, baik intervensi klinis seperti CBT maupun intervensi yang didasarkan pada teori pemberdayaan (Trabold et al., 2018). Menurut Eckhardt et al. (2013), terapi yang difokuskan pada perempuan yang mengalami IPV dapat menjadi efektif apabila partisipan perempuan dalam terapi tersebut menyelesaikan setiap sesi terapi hingga sesi yang terakhir. Apabila terjadi atrisi dalam terapi, menurut penelitian Eckhardt et al., hal ini akan mengurangi efektifitas terapi dan memengaruhi hasil dari terapi dalam penelitian tersebut.

Sebagai implikasi untuk praktisi, hasil-hasil penelitian menunjukkan bahwa terapi yang didasarkan pada model Cognitive-Behavioural seperti CBT, terbukti dapat menurunkan gejala-gejala depresi secara umumnya maupun secara khususnya dalam kasus kekerasan terhadap pasangan perempuan (Trabold et al., 2018). Secara khusus, teknik CBT paling menolong klien yang mengalami depresi adalah teknik penstrukturan-ulang kognitif, di mana dalam teknik ini klien secara aktif menantang dan mengganti kognisinya yang keliru dan terdistorsi (Trabold et al., 2018). Menurut Trabold et al., teknik kognitif ini dapat menjadi lebih efektif apabila dikombinasikan dengan teknik perilaku. Salah satu teknik perilaku yang sering digunakan adalah aktivasi perilaku. Menurut Trabold et al., komponen utama dalam teknik ini adalah (1) membantu klien untuk mengindentifikasi area penting dalam hidupnya dan values yang terdapat pada area tersebut, (2) mengimplementasikan values tersebut dalam aktivitas-aktivitas sehari-hari, sehingga klien dapat menghidupi sebuah hidup yang bermakna baginya, dan (3) terapis 
dapat memberikan dukungan baik secara sosial maupun emosional kepada klien, sehingga klien tidak mudah menyerah dalam melakukan terapi serta mempunyai resiliensi yang baik.

Dalam mengimplementasikan intervensi $C B T$, penting untuk menggabungkan terapi yang didasarkan pada teori pemberdayaan dengan intervensi CBT ini. Karena intervensi yang didasarkan pada teori pemberdayaan mengutamakan keamanan dan juga kebutuhan dasar perempuan yang mengalami IPV dan KDP. Sehingga, dengan dipenuhinya kebutuhan dasar (seperti makanan dan tempat tinggal) dan dipenuhinya rasa aman, maka perempuan tersebut dapat berfokus untuk menyelesaikan masalahmasalah emosional dan gejala depresinya. Jadi, pembentukan safety space bagi perempuan yang mengalami IPV dan KDP adalah penting untuk membuat perempuan tersebut memiliki rasa aman bagi dirinya, sehingga ia dapat berfokus untuk menerima intervensi CBT.

\section{Penutup}

Berdasarkan review literatur di atas, maka dapat disimpulkan bahwa fenomena IPV dan KDP di Indonesia adalah sebuah permasalahan yang penting dan urgent untuk segera diintervensi. Beberapa jenis metode penanganan telah dibahas dalam review ini, dan salah satu metode efektif yang telah diterapkan dalam kasus kekerasan terhadap pasangan perempuan secara umumnya adalah metode yang didasarkan pada perspektif CognitiveBehavioural seperti CBT. CBT berfokus pada mengubah konsep berpikir seseorang yang keliru, dan mengubah kognisikognisi maladaptif tersebut menjadi kognisi-kognisi yang positif dan adaptif (Beck et al., 1979). Oleh sebab itu, adalah penting untuk melaksanakan sebuah pilot study di Indonesia yang didasarkan pada kajian perspektif Cognitive-Behavioural untuk mengujicobakan intervensi CBT pada perempuan yang mengalami kasus IPV atau KDP. Intervensi CBT ini juga harus melihat aspek-aspek kebutuhan perempuan yang mengalami IPV atau KDP seperti safety planning, ketersediaan safety space, dan tercukupinya kebutuhan dasar seperti makanan dan rasa aman. Aspek-aspek ini menjadi fondasi dasar yang harus dipenuhi, sebelum intervensi CBT dapat terlaksana dengan efektif.

\section{Daftar Pustaka}

Alaggia, R., Regehr, C., \& Jenney, A. (2012). Risky business: An ecological analysis of intimate partner violence disclosure. Research on Social Work Practice, 22(3), 301-312. doi: $\underline{10.1177 / 1049731511425503}$

American Psychiatric Association. (2013). Diagnostic and statistical manual of mental disorders. DSM (5th ed.). Washington, DC: American Psychiatric Association. doi: 10.1176/ appi.books.9780890425596.744053

Ayu, S. M., Hakimi, M., \& Hayati, E. N. (2016). Kekerasan dalam pacaran dan kecemasan remaja putri di kabupaten Purworejo. Jurnal Kesehatan Masyarakat (Journal of Public Health), 6(1), 61-74. doi: $10.12928 /$ kesmas.v6i1.1067

Badan Pusat Statistik. (2012). Survei demografi dan kesehatan Indonesia 2012. Jakarta: Badan Pusat Statistik.

Baldwin, K. (2012). Factbox: The worst and best G20 countries for women. Thomson Reuters Foundation. Retrieved from http://news.trust.org/item/20120613010 100-sk134/

Banyard, V. L. (2011). Who will help 
prevent sexual violence: Creating an ecological model of bystander intervention. Psychology of Violence, 1(3), 216-229. doi: 10.1037/a0023739

Barlow, D. H. (2008). Clinical handbook of psychological disorders: A step-by-step treatment manual. (D. H. Barlow, Ed.) (4th ed.). New York: The Guilford Press.

Beck, A. T. (2005). The current state of cognitive therapy: A 40-year retrospective. Archives of General Psychiatry, 62(9), 953-959. doi: 10.1001/archpsyc.62.9.953

Beck, A. T., Rush, A. J., Shaw, B. F., \& Emery, G. (1979). Cognitive therapy of depression. New York: Guilford Press.

Bonomi, A. E., Anderson, M. L., Rivara, F. P., \& Thompson, R. S. (2009). Health care utilization and costs associated with physical and nonphysical-only intimate partner violence. Health Services Research, 44, 1052-1067. doi: 10.1111/j.1475-6773.2009.00955.x

Breiding, M. J., Black, M. C., \& Ryan, G. W. (2008). Prevalence and risk factors of intimate partner violence in eighteen U.S. states/territories in 2005. American Journal of Preventive Medicine, 34(2), 112-118. doi: $\underline{10.1016 /}$ j.amepre.2007.10.001

Breiding, M. J., Chen, J., \& Black, M. C. (2014). Intimate partner violence in the United States - 2010. Centers for Disease Control and Prevention. Atlanta, GA.

Bronfenbrenner, U. (2004). Developmental ecology through space and time: A future perspective. In P. Moen, G. H. Elder, Jr., \& K. Luscher (Eds.), Examining lives in context: Perspectives on the ecology of human development (pp. 619 - 647). Washington, DC: American Psychological Association. doi:

\section{$10.1037 / 10176-018$}

Bronfenbrenner, U. (1977). Toward an experimental ecology of human development. American Psychologist, 32(7), 513-531.

Centers for Disease Control and Prevention. (2014). Understanding intimate partner violence: Fact sheet. Centers for Disease Control and Prevention. Retrieved from http://www.cdc.gov/ncipc/dvp/ipv fac tsheet.pdf

Comer, R. J. (2010). Fundamentals of abnormal psychology (6th ed.). New York: Worth Publisher.

Connolly, J., Friedlander, L., Pepler, D., Craig, W., \& Laporte, L. (2010). The ecology of adolescent dating aggression: Attitudes, relationships, media use, and socio-demographic risk factors. Journal of Aggression, Maltreatment, and Trauma, 19(5), 469491. doi: $10.1080 / 10926771.2010 .495028$

Constantino, R. E., Braxter, B., Ren, D., Burroughs, J. D., Doswell, W. M., Wu, L., ... Greene, W. B. (2015). Comparing online with face-to-face HELPP intervention in women experiencing intimate partner violence. Issues in Mental Health Nursing, 36, 430-438. doi: $10.3109 / 01612840.2014 .991049$

Cormier, S., \& Nurius, P. S. (2003). Interviewing and change strategies for helpers: Fundamental skills and cognitive behavioral interventions. in (5th ed.). Melbourne: Thomson Brooks/Cole.

Cougle, J. R., Resnick, H., \& Kilpatrick, D. G. (2009). A prospective examination of PTSD symptoms as risk factors for subsequent exposure to potentially traumatic events among women. Journal of Abnormal Psychology, 118(2), 405-411. doi: 10.1037/a0015370

Craske, M. G., \& Barlow, D. H. (2008). 
Panic disorder and agoraphobia. In D. H. Barlow (Ed.), Clinical handbook of psychological disorders: A step-by-step treatment manual (4th ed., pp. 1-64). New York: The Guilford Press.

Crespo, M., \& Arinero, M. (2010). Assessment of the efficacy of a psychological treatment for women victims of violence by their intimate male partner. Spanish Journal of Psychology, 13, 849-863. doi: 10.1017/S113874160000250X

Cuijpers, P., Karyotaki, E., Weitz, E., Andersson, G., Hollon, S. D., \& Van Straten, A. (2014). The effects of psychotherapies for major depression in adults on remission, recovery, and improvement: A meta-analysis. Journal of Affective Disorders, 159, 118-126. doi: 10.1016/j.jad.2014.02.026

Dobson, K. S. (2010). Handbook of cognitivebehavioral therapies. (K. S. Dobson, Ed.) (3rd ed.). New York: The Guilford Press.

Eckhardt, C. I., Murphy, C. M., Whitaker, D. J., Sprunger, J., Dykstra, R., \& Woodard, K. (2013). The effectiveness of intervention programs for perpetrators and victims of intimate partner violence. Partner Abuse, 4, 196231. doi: $10.1891 / 1946-6560.4 .2 .196$

Ellis, A., \& Dryden, W. (2007). The practice of rational emotive behavior therapy (2nd ed.). New York: Springer.

Foshee, V. A., Reyes, H. L. M., \& Ennett, S. T. (2010). Examination of sex and race differences in longitudinal predictors of the initiation of adolescent dating violence perpetration. Journal of Aggression, Maltreatment and Trauma, 19(5), 492-516. doi: $\underline{10.1080 /}$ 10926771.2010 .495032

Foshee, V. A., Reyes, H. L. M., Ennett, S. T., Suchindran, C., Mathias, J. P.,
Karriker-Jaffe, K. J., ... Benefield, T. S. (2011). Risk and protective factors distinguishing profiles of adolescent peer and dating violence perpetration. Journal of Adolescent Health, 48(4), 344$350 . \quad$ doi: $\underline{10.1016 /}$ j.jadohealth.2010.07.030

Gilbert, L., El-Bassel, N., Manuel, J., Wu, E., Go, H., Golder, S., ... Sanders, G. (2006). An integrated relapse prevention and relationship safety intervention for women on methadone: Testing short-term effects on intimate partner violence and substance use. Violence and Victims, 21, 657-672. doi: 10.1891/0886-6708.21.5.657

Gloaguen, V., Cottraux, J., Cucherat, M., \& Blackburn, I. M. (1998). A metaanalysis of the effects of cognitive therapy in depressed patients. Journal of Affective Disorders, 49(1), 59-72. doi: $\underline{10.1016 / S 0165-0327(97) 00199-7}$

Hollon, S. D. (2003). Does cognitive therapy have an enduring effect? Cognitive Therapy and Research,27(1), 71-75. doi: 10.1023/A:1022538713914

Iverson, K. M., Gradus, J. L., Resick, P. A., Suvak, M. K., Smith, K. F., \& Monson, C. M. (2011). Cognitive-behavioral therapy for PTSD and depression symptoms reduces risk for future intimate partner violence among interpersonal trauma survivors. Journal of Consulting and Clinical Psychology, 79(2), 193-202. doi: 10.1037/a0022512

Iverson, K. M., Lester, K., \& Resick, P.A. (2011). Psychosocial treatments. In W. Benedek (Eds.), Clinical manual for the management of PTSD (pp. 157-203). Arlington, VA: American Psychiatric Publishing, Inc.

Jain, S., Buka, S. L., Subramanian, S. V., \& Molnar, B. E. (2010). Neighborhood 
predictors of dating violence victimization and perpetration in young adulthood: A multilevel study. American Journal of Public Health, 100(9), $\quad 1737-1744 . \quad$ doi: $\quad \underline{10.2105 /}$ AJPH.2009.169730

Johnson, D. M, Zlotnick, C., \& Perez, S. (2011). Cognitive behavioral treatment of PTSD in residents of battered women's shelters: results of a randomized clinical trial. Journal of Consulting and Clinical Psychology, 79(4), 542-551. doi: 10.1037/a0023822

Kaslow, N. J., Leiner, A. S., Reviere, S., Jackson, E., Bethea, K., Bhaju, J., ... Thompson, M. P. (2010). Suicidal, abused African American women's response to a culturally informed intervention. Journal of Consulting and Clinical Psychology, 78(4), 449-458. doi: 10.1037/a0019692

Komnas Perempuan. (2012). Stagnansi sistem hukum: Menggantung asa perempuan korban, catatan KTP tahun 2011. Jakarta. Retrieved from https://www.komnasperempuan.go.id /file/pdf_file/Catatan

Tahunan/10.PP5_CATAHU 2012.pdf

Komnas Perempuan. (2013). Korban berjuang, publik bertindak: Mendobrak stagnansi sistem hukum, catatan KTP tahun 2012. Jakarta. Retrieved from https://www.komnasperempuan.go.id /file/pdf_file/Catatan

Tahunan/11.PP5_CATAHU 2013.pdf

Komnas Perempuan. (2014). Kegentingan kekerasan seksual: Lemahnya upaya penanganan negara, catatan KTP tahun 2013. Jakarta. Retrieved from https://www.komnasperempuan.go.id /file/pdf_file/Catatan Tahunan/12.PP5_CATAHU 2014.pdf

Komnas Perempuan. (2015). Kekerasan terhadap perempuan: Negara segera putus impunitas pelaku, catatan KTP 2014. Jakarta. Retrieved from https://www.komnasperempuan.go.id /file/pdf_file/Catatan

Tahunan/13.PP5_CATAHU-2015.pdf

Komnas Perempuan. (2016). Kekerasan terhadap perempuan meluas: Negara urgen hadir hentikan kekerasan terhadap perempuan di ranah domestik, komunitas dan negara, catatan KTP tahun 2015. Jakarta. Retrieved from https://www.komnasperempuan.go.id /file/pdf_file/Catatan Tahunan/14.PP5_CATAHU 2016.pdf

Komnas Perempuan. (2017). Labirin kekerasan terhadap perempuan: Dari gang rape hingga femicide, alarm bagi negara untuk bertindak tepat, catatan KTP 2016. Jakarta. Retrieved from https://www.komnasperempuan.go.id /file/pdf_file/2017 Siaran Pers/Lembar Fakta Catahu 2017.pdf

Komnas Perempuan. (2018). Tergerusnya ruang aman perempuan dalam pusaran politik populisme, catatan KTP 2017. Jakarta. Retrieved from https://www.komnasperempuan.go.id /file/pdf_file/2018/Publikasi/Catatan Tahunan Kekerasan Terhadap Perempuan 2018.pdf

Marcelina, L. (2008). Dampak psikologis remaja yang pernah mengalami kekerasan seksual. Universitas Katolik Soegijapranata, Semarang.

Max, W., Rice, D. P., Finkelstein, E., Bardwell, R. A., \& Leadbetter, S. (2005). The economic toll of intimate partner violence against women in the United States. Violence and Victims, 19, 259-272. doi: 10.1891/vivi.19.3.259. 65767

Page, A., \& Stritzke, W. (2006). Clinical psychology for trainees: Foundations of science-informed practice. Cambridge: 
Cambridge University Press.

Reed, G. L., \& Enright, R. D. (2006). The effects of forgiveness therapy on depression, anxiety, and posttraumatic stress for women after spousal emotional abuse. Journal of Consulting and Clinical Psychology, 74(5), 920-929. doi: $\underline{10.1037 / 0022-006 X .74 .5 .920}$

Rivara, F. P., Anderson, M. L., Fishman, P., Bonomi, A. E., Reid, R. J., Carrell, D., \& Thompson, R. S. (2007). Healthcare utilization and costs for women with a history of intimate partner violence. American Journal of Preventive Medicine, 32(2), 89-96. doi: 10.1016/j.amepre. 2006.10.001

Safitri, W. A. (2013). Dampak kekerasan dalam berpacaran: Studi kasus pada mahasiswa Fakultas Ilmu Sosial dan Ilmu Politik Universitas Jember. Skripsi (tidak dipublikasikan). Universitas Jember.

Santrock, J. W. (2012). Life-span development (14th ed.). New York: The McGrawHill Companies.

Scher, C. D., Ingram, R. E., \& Segal, Z. V. (2005). Cognitive reactivity and vulnerability: Empirical evaluation of construct activation and cognitive diatheses in unipolar depression. Clinical Psychology Review, 25(4), 487510. doi: 10.1016/j.cpr.2005.01.005

Scott, J., \& Freeman, A. (2010). Beck's cognitive therapy. In N. Kazantzis, M. A. Reinecke, \& A. Freeman (Eds.), Cognitive and behavioral theories in clinical practice (pp. 28-75). New York, NY: The Guilford Press.

Sinaga, T. (2007). Pengetahuan dan sikap remaja putri terhadap aborsi dari kehamilan tidak dikehendaki di Sekolah Menengah Umum Negeri I Pematang Siantar. Skripsi (tidak dipublikasikan). Universitas Sumatera Utara, Medan.

Strunk, D. R., \& DeRubeis, R. J. (2001).
Cognitive therapy for depression: A review of its efficacy. Journal of Cognitive Psychotherapy, 15(4), 289-297. doi: $\underline{10.1891 / 0889-8391.15 .4 .289}$

Sullivan, C. M., Bybee, D. I., \& Allen, N. E. (2002). Findings from a communitybased program for battered women and their children. Journal of Interpersonal Violence, 17(9), 915-936. doi: $10.1177 / 0886260502017009001$

Thomson Reuters Foundation. (2017). Thomson Reuters foundation annual report. Retrieved from https://annualreport.thomsonreuters.com/download s/thomson-reuters-foundation-report2017.pdf

Trabold, N., McMahon, J., Alsobrooks, S., Whitney, S., \& Mittal, M. (2018). A systematic review of intimate partner violence interventions: State of the field and implications for practitioners. Trauma, Violence, and Abuse, 1-15. doi: 10.1177/152483801 $\underline{8767934}$

UNICEF. (2016). Child marriage in Indonesia: Progress on pause. Retrieved from https://www.unicef.org/indonesia/UN ICEF_Indonesia_Child_Marriage_Rese rach_Brief_.pdf

United Nations. (2011). World population prospects: The 2010 revision. New York. Retrieved from http://www.un.org/en/ development/desa/population/publica tions/pdf/trends/WPP2010/WPP2010_ Volume-I_Comprehensive-Tables.pdf

Vagi, K. J., Rothman, E. F., Latzman, N. E., Tharp, A. T., Hall, D. M., \& Breiding, M. J. (2013). Beyond correlates: A review of risk and protective factors for adolescent dating violence perpetration. Journal of Youth and Adolescence, 42(4), 633-649. doi: $\underline{10.1007 / \mathrm{s} 10964-013-9907-7}$

Weeks, L. E., \& LeBlanc, K. (2011). An 
ecological synthesis of research on older women's experiences of intimate partner violence. Journal of Women and Aging, 23(4), 283-304. doi: 10.1080/ $\underline{08952841.2011 .611043}$

World Health Organization. (2005). WHO multi-country study on women's health and domestic violence against women: Summary report of initial on prevalence, health outcomes and women's responses. Geneva, Switzerland.

World Health Organization. (2013a). Global and regional estimates of violence against women: Prevalence and health effects of intimate partner violence and non-partner sexual violence. Geneva, Switzerland. Retrieved from http://www.who.int/ reproductivehealth/publications/viole nce/9789241564625/en/

World Health Organization. (2013b). Unintended pregnancy: Toward understanding the issues and addressing the need gaps. Geneva.

Young, J. E., Rygh, J. L., Weinberger, A. D., \& Beck, A. T. (2008). Cognitive therapy for depression. In D. H. Barlow (Ed.), Clinical handbook of psychological disorders: A step-by-step treatment manual (4th ed., pp. 250-305). New York: The Guilford Press.

Zimmerman, M. A. (1995). Psychological empowerment: Issues and illustrations. American Journal of Community Psychology, 23(5), 581-599. doi: $\underline{10.1007 / B F 02506983}$ 